\title{
Latitudinal patterns of bird richness, diversity and abundance in Polylepis australis mountain forest of Argentina
}

\author{
LAURA M. BELLIS, LUIS RIVERA, NATALIA POLITI, EDUARDO MARTÍN \\ M. LAURA PERASSO, FRANCISCO CORNELL and DANIEL RENISON
}

\begin{abstract}
Summary
Many South American hotspots of bird endemism are found in Polylepis dominated forests. Although the avifauna of Polylepis forests has been relatively well studied in the tropical Andes, little is known in Argentina. In this study, we characterize the Argentine avifauna of Polylepis australis forests along their entire latitudinal gradient of distribution and provide a first systematic bird list and their conservation status. Fieldwork was carried out from 1,500 to 2,800 m a.s.l. in three study sites: North (Jujuy province), Centre (Tucumán province) and South (Córdoba province); we surveyed 30 point counts per site. We recorded 543 individuals belonging to 50 bird species; two subspecies are endemic to the South site and four species are typical Polylepis forest birds of the North and Centre sites. We identified four species of conservation concern; one globally threatened and three declining at regional level. Bird richness and abundance decreased with latitude; and equitability showed an inverse pattern. Sorenson's similarity index ranged from $12 \%$ to $40 \%$ showing a large latitudinal turnover in avian communities. Disturbance-sensitive species were the most diverse group in the North site. Variations in species richness, evenness and guild composition may be a response to latitude, but also to differences in habitat complexity and food availability, which appear to be a consequence of forest degradation at the South site. We recommend: (I) the enlargement of Calilegua National Park to include the Polylepis australis belt to assure the conservation of many disturbance-sensitive species which could decline or disappear in degraded areas; (2) management of Quebrada del Condorito National Park to increase the forest structure complexity and therefore provide habitat for disturbance-sensitive species.
\end{abstract}

\section{Resumen}

Muchas áreas de especiación de aves endémicas de Sudamérica se encuentran en bosques dominados por Polylepis. Aunque la avifauna de estos bosques ha sido relativamente bien estudiada en los Andes tropicales, en Argentina su conocimiento es escaso. En este estudio, caracterizamos la avifauna de los bosques de Polylepis australis de Argentina a lo largo de su gradiente latitudinal de distribución y confeccionamos la primer lista sistemática de aves y su estado de conservación. El trabajo de campo se realizó en una faja altitudinal de 1,500 a 2,800 m snm en tres sitios de estudio: Norte (provincia de Jujuy), Centro (provincia de Tucumán) y Sur (provincia de Córdoba) donde se relevaron 30 puntos de conteo por sitio. Registramos 543 individuos pertenecientes a 50 especies de aves; dos subespecies son endémicas del sitio Sur y cuatro especies son aves típicas de los bosques de Polylepis de los sitios Norte y Centro. Identificamos cuatro especies de interés para la conservación, una globalmente amenazada y tres disminuyendo a nivel regional. La riqueza y la abundancia de aves decreció con la latitud; la 
equitatividad mostró un patrón inverso. El índice de similitud de Sorenson osciló entre $12 \%$ al $40 \%$ mostrando un gran recambio latitudinal en las comunidades de aves. Las variaciones en la riqueza, equitatividad y en la composición de gremios responderían a la latitud pero también a las diferencias en la complejidad del hábitat y en la disponibilidad de alimento como consecuencia de la degradación del bosque en el sitio Sur. Recomendamos: (I) ampliar el Parque Nacional Calilegua para incluir un área de Polylepis australis y asegurar la conservación de muchas especies sensibles al disturbio que podrían desminuir o desaparecer en áreas degradadas; (2) manejar el Parque Nacional Quebrada del Condorito para incrementar la complejidad estructural del bosque y proveer hábitats para especies sensibles al disturbio.

\section{Introduction}

Forests dominated by the genus Polylepis characterize the higher mountain regions of South America and are distributed in small patches primarily restricted to ravines and rock outcrops. Recent studies suggest that the peculiar distribution of Polylepis trees may be the result of thousands of years of human activities (Kessler 2002, Renison et al. 2006). A long history of logging (Fjeldså and Kessler 1996, Renison et al. 2006), fire management (e.g. Renison et al. 2002, Cingolani et al. 2008), overgrazing (e.g. Teich et al. 2005, Cingolani et al. 2008), and soil degradation (Renison et al. 2006, Torres et al. 2008) has reduced these forests to small isolated patches restricted to rocky outcrops where the impact of livestock and burning is low (Fjeldså and Kessler 1996; Renison et al. 2006, Cingolani et al. 2008; Coblentz and Keating 2008). Consequently, Polylepis forests are now considered one of the most threatened Neotropical vegetation types (Jameson and Ramsay 2007). Despite the limited extent and patchy distribution of Polylepis forest, they still harbour a high bird species richness including many endemics that have been relatively well studied in the tropical Andes (Fjeldså 1993, Kessler et al. 2001, Herzog et al. 2003, Fjeldså and Kessler 1996, Cahill and Matthysen 2007, Lloyd and Marsden 2008, Lloyd 2008a,b). However, in Argentina quantitative data for Polylepis forest bird communities are scarce.

In Argentina, several Important Bird Areas (IBAs) include Polylepis forests with globally threatened bird species (Di Giácomo 2005) and restricted-range bird species belonging to three Endemic Bird Areas (EBA): EBA 056 'High Andes of Bolivia and Argentina', EBA 057 'Argentina and south Bolivian yungas', and EBA 058 'Mountains of central Argentina' (Stattersfield et al. 1998). However, very few attempts have been made to study avian communities of Polylepis forests. To our knowledge, there is only one study that compares avian composition among forests of $P$. australis, $P$. tomentella and P. hieronymi (Renison et al. in press) and two non-specific studies that included, but were not exclusive to, Polylepis forests in the mountains of central Argentina (Heil et al. 2007, García et al. 2008).

To initiate the study of Polylepis forest birds in Argentina, our goal is to perform a first characterization of Polylepis australis bird assemblages along their latitudinal gradient of distribution. Specifically we determined: a) richness, equitability, diversity and abundance of avian communities; b) bird species composition turnover; and c) bird conservation status. These data may be useful to direct future studies and conservation priorities and serve as a baseline for monitoring avifaunal changes over time.

\section{Methods}

\section{Study areas}

Fieldwork was carried out in P. australis forest fragments located in the eastern slopes of the Andes in northern Argentina and in Sierras Grandes of Argentina. We selected three sampling sites along the P. australis latitudinal gradient (Figure 1). The North site corresponds to Alto 
Calilegua, Jujuy province $\left(23^{\circ} 37^{\prime} \mathrm{S}, 64^{\circ} 54^{\prime} \mathrm{W} ; 2,714 \mathrm{~m}\right)$ and Centre site corresponds to La Ovejeria, Tucumán province $\left(26^{\circ} 50^{\prime} \mathrm{S}, 65^{\circ} 45^{\prime} \mathrm{W} ; 2,400 \mathrm{~m}\right)$. These two sites belong to the upper cloud forest of the southern Yungas (or subtropical montane forests) where P. australis and Alnus acuminata forests are followed by alpine Andean grasslands and meadows (Cabrera 1976). Annual vertical precipitation reaches $1,500 \mathrm{~mm}$ and is mainly concentrated in the austral summer (December-March). Fog and horizontal precipitation can be equivalent to the vertical precipitation or even exceed this volume (Hunzinger 1995). The South site corresponds to Sierras Grandes, Córdoba province $\left(31^{\circ} 58^{\prime} \mathrm{S}, 64^{\circ} 56^{\prime} \mathrm{W} ; 1,950 \mathrm{~m}\right)$ which is located in a small chain of mountains $400 \mathrm{~km}$ east of the Andean Mountains. In the South site, P. australis

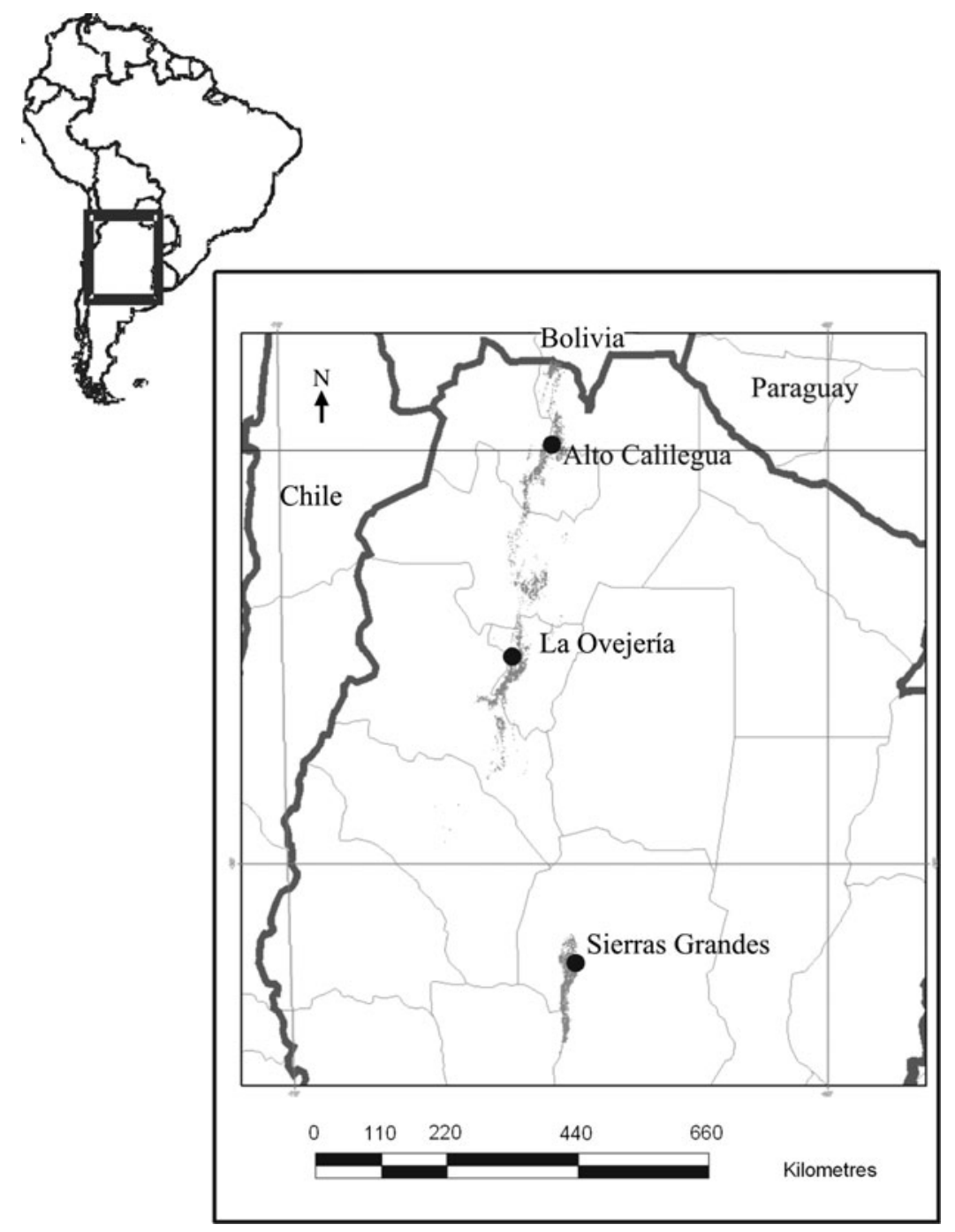

Figure 1. Distribution range of Polylepis australis forest to Argentina. Filled circles represent the different study sites. North site: Alto Calilegua (Jujuy province) and Centre site: La Ovejeria (Tucuman province) are located on the Andean slopes of the Yungas, and South site: Sierras Grandes in the mountains of central Argentina. 
dominates the upper strata of woodlands and shrublands with other less abundant woody species, such as: Maytenus boaria, Escallonia cordobensis, Berberis hieronimii, Satureja spp., and Gaultheria poepigii (Cabido and Acosta 1985, Cingolani et al. 2004). Mean annual precipitation is $840 \mathrm{~mm}$, with $83 \%$ of rainfall concentrated in the warmer months (October to April, Renison et al. 2002).

\section{Bird survey}

Bird data were collected during the summer season (January to March 2006) when bird richness is highest due to the arrival of summer resident species that use this area for breeding. Additionally, during the summer, differences in bird communities are easier to detect due to their territorial behaviour, compared to their aggregated distribution in the winter when large mixed flocks can be seen (Ordano 1996, García et al. 2008). Bird species and abundance were quantified using 1o-minute point counts randomly distributed in each $P$. australis study site. This count period maximized probability of bird detection in cryptic species (Bibby et al. 1992, Ralph et al. 1995, Lee and Marsden 2008). We located an average of 30 survey points separated by at least $150 \mathrm{~m}$ (or 1o min travelling distance) to avoid double-counts between neighbouring points. At each point, the surveyor waited $5 \mathrm{~min}$ as a settling down period before starting the counts (Bibby et al. 1992, Ralph et al. 1995). Birds occurring within 50-m fixed-radius of each point were recorded visually or acoustically. Point counts were surveyed twice in favourable weather conditions. Daily counts included 3-hour periods after sunrise. To reduce biases, experienced observers conducted all bird surveys (LR and EM with 10 and four years of experience, respectively). Nocturnal species and species that only overflew the forest (e.g. Andean Condor Vultur gryphus) were not considered. Taxonomic identification of birds was determined following Mazar-Barnett and Pearman (2001).

\section{Data analysis}

As a measure of relative density we calculated encounter rates per bird species (ER) recorded in each point count. ER was expressed as number of detections per point (IO min and 0.78 ha) for each species recorded. Richness and diversity of bird communities were calculated using EstimateS v.8.o software (Colwell 2006). Sample species richness was estimated from the sample-based rarefaction curves (Mau Tau; Sobs; Mao et al. 2005). Sample was randomised 50 times for each dataset. To examine changes in species composition along the latitudinal gradient, the robust bootstrap estimator ( $\mathrm{S}_{\text {boot; }}$ Colwell and Coddington 1994) was used as a richness measure and Simpson's index (I/D) as a diversity measure. This index better reflects the entire species abundance distribution than other indices of the same general form (Magurran 1988). We also calculated the Simpson Equitability index $\left(\mathrm{S}_{\mathrm{E}}\right.$, Magurran 1988) to compare along the gradient the evenness with which individuals were distributed among the different species. Changes in composition of avian communities along the gradient (beta diversity) were tested with the Sorenson qualitative index (Magurran 1988).

We also analyzed the contribution to the Polylepis bird assemblage from birds of surrounding habitat types: (I) subtropical montane forests of the Andes (i.e., selva Tucumano-Boliviano), (2) shrublands/grasslands, or (3) not restricted to a single habitat, here defined as generalists (Fjeldså and Krabbe 1990, Stotz et al. 1996, Narosky and Yruzieta 2003). Functional groups were established according to habitat use of species as determined from the literature (Fjeldså and Kessler 1996, Dardanelli et al. 2006). Groups were classified as: disturbance-sensitive species (DS, species that use mainly the forest: understorey, ground, medium stratum or canopy), disturbance-tolerant species (DT, species that primarily use forest edges, shrublands and open areas) and neutral species ( $\mathrm{N}$, habitat generalists). Here we defined habitat in the narrow sense of vegetation structure rather than as the full array of biotic and abiotic factors in the environment. 
We tested changes on bird communities among sites with a Kruskal-Wallis test and differences in the number of species of functional groups within and among sites with $\chi^{2}$ goodness of fit test (Zar 1984).

\section{Results}

We recorded a total of 543 birds belonging to 50 species (Table 1 ). The most commonly recorded species were: Rufous-collared Sparrow Zonotrichia capensis with $27.6 \%(n=150)$ of all detected individuals, followed by Chiguanco Thrush Turdus chiguanco 11.9\% $(n=65)$, Red-tailed Comet Sappho sparganura $5.9 \%(n=32)$ and Brown-capped Tit-spinetail Leptasthenura fuliginiceps $2.8 \%(n=15)$. Bird richness $\left(S_{\text {boot }}\right)$ decreased with latitude (Kruskall-Wallis $S_{\text {boot }}=14 \cdot 42$, $P=0.0007)$ with more species recorded at North and Centre sites than at the South site. Bird diversity followed a different pattern (Kruskall-Wallis $1 / D=21.88 ; P<0.0001$ ), with the highest diversity at the Centre site, intermediate at the South site and the lowest at the North site. The difference in richness - diversity patterns were due to a strong North - South increment in equitability index (Table 2).

Sorenson's similarity index was low, showing a species turnover along the latitudinal gradient. North and Centre sites shared 11 species (40\%), North and South shared five species (12\%) and Centre and South sites shared seven species (34\%). Approximately half of the species in each site occurred only in that site; in the North and Centre sites species richness was determined by species associated with subtropical montane forest, while the number of species of shrublands and grassland was similar in the three sites (Figure 2).

In terms of habitat use groups (Table 2), there was a significantly higher number of disturbance-sensitive species (DS) detected in the North site $\left(\chi^{2}=8.81, P=0.01\right)$. The Centre and South sites did not show significant differences in the richness of sensitive, tolerant or neutral species $\left(\chi^{2}=1.51 P=0.46 ; \chi^{2}=0.86, P=0.65\right.$, respectively). Comparing the number of species per habitat group along the gradient, only DS of the North site showed significant differences $\left(\chi^{2}=6.93, P=0.03\right)$ in respect to the other sites.

\section{Discussion}

Our results show a general pattern of decrease in bird richness and number of disturbancesensitive species of Polylepis bird communities with latitude, coupled with an increment in the evenness of the species distribution. The lower equitability index at the North site resulted from the higher dominance of forest-dependent birds which caused a reduction of diversity index at this site. Many studies show that diversity can change with changes in evenness independently of species richness. That is, a community with evenly distributed species appears more diverse than a community that is dominated by a few species (Magurran 1988, Stirling and Wilsey 2001).

Besides this latitudinal avifaunal pattern, we found a high species turnover among sites. The species turnover could be influenced by vegetation types within and surrounding P. australis forest patches. North and Centre sites are structurally rich and their associations with other plant species such as vines, ferns and bromeliads makes them favourable feeding habitats for many birds (Fjeldså 1993). On the contrary, in the South site P. australis usually produces lateral basal ramifications forming shrublands and only occasionally forms dense forest stands (Enrico et al. 2004, Cingolani et al. 2004, 2008, Renison et al. 2006). These differences in the growth habit of P. australis change the forest structure (Kessler 2000) and availability, so could be inducing a reduction in bird richness (Bellis et al. unpubl. data). The positive response of bird species richness to habitat complexity has been well documented in tropical forests (Bennett et al. 2004, Watson et al. 2004, Barlow et al. 2006). Specifically in Polylepis forests, habitat complexity and quality are important determinants of avian diversity (Terborgh 1977, Kessler et al. 2001, Lloyd and Marsden 2008). Habitat features such as density of large trees, vegetation cover, and patch size are very important for many forest-dependent birds (Lloyd 2008a, b, Lloyd and Marsden 
Table 1. List of bird species and encounter rates expressed as number of detections per point (10-min. sampled period) recorded in Polylepis australis forest of Argentina. North (Jujuy province), Centre (Tucumán province) and South (Córdoba province) sites. DS: disturbance-sensitive species, DT: disturbance-tolerant species and N: neutral species. (*) Endemic subspecies. (+) Species closely associated with P. australis forests.

\begin{tabular}{|c|c|c|c|c|}
\hline \multirow[t]{2}{*}{ Species Names } & \multicolumn{3}{|l|}{ Sites } & \multirow{2}{*}{$\begin{array}{l}\text { Functional } \\
\text { Group }\end{array}$} \\
\hline & North & Centre & South & \\
\hline Nothoprocta pentlandii & $\mathrm{O}$ & 0.07 & $\mathrm{o}$ & DS \\
\hline Falco sparverius & o & 0.07 & o & DT \\
\hline Penelope dabbenei & 0.10 & o & o & DS \\
\hline Columba maculosa & o & o & 0.10 & $\mathrm{~N}$ \\
\hline Leptotila verreauxi & o & 0.03 & 0.03 & DS \\
\hline Zenaida auriculata & o & o & 0.03 & $\mathrm{~N}$ \\
\hline Aratinga mitrata & 0.93 & o & o & DT \\
\hline Bolborhynchus aymara & o & 0.30 & 0.27 & DT \\
\hline Bolborhynchus aurifrons & 0.4 & o & o & DT \\
\hline Aeronautes andecolus & o & o & 0.20 & DT \\
\hline Amazilia chionogaster & o & 0.07 & o & DS \\
\hline Colibri coruscans & 0.13 & 0.03 & o & DT \\
\hline Sappho sparganura & 0.90 & 0.13 & 0.03 & $\mathrm{~N}$ \\
\hline Colaptes melanochloros & o & o & 0.13 & DS \\
\hline Cinclodes atacamensis & o & 0.07 & o & DT \\
\hline Cinclodes fuscus & 0.10 & o & 0.03 & DT \\
\hline Cinclodes oustaleti olrogi* & o & o & 0.03 & DT \\
\hline Cranioleuca pyrrhophia & 0.10 & o & o & DS \\
\hline Leptasthenura fuliginiceps & 0.20 & 0.20 & 0.10 & DS \\
\hline Leptasthenura platensis & o & o & 0.03 & DT \\
\hline Phacellodomus maculipectus & 0.07 & o & o & DT \\
\hline Phacellodomus striaticeps ${ }^{+}$ & 0.10 & o & o & DS \\
\hline Scytalopus superciliaris & o & 0.17 & o & DS \\
\hline Anairetes parulus & o & o & 0.33 & DT \\
\hline Knipolegus signatus & 0.03 & o & o & DS \\
\hline Mecocerculus leucophrys & 0.17 & 0.17 & o & DS \\
\hline Myiotheretes striaticollis & 0.20 & 0.10 & o & DS \\
\hline Ochthoeca leucophrys & 0.07 & o & o & DT \\
\hline Sayornis nigricans & o & 0.03 & o & DT \\
\hline Tyrannus melancholicus & $\mathrm{o}$ & 0.03 & o & $\mathrm{N}$ \\
\hline Haplochelidon andecola & $\mathrm{o}$ & 0.60 & $\mathrm{o}$ & DT \\
\hline Troglodytes aedon & o & 0.33 & 0.13 & $\mathrm{~N}$ \\
\hline Turdus chiguanco & 0.53 & 1.17 & 0.47 & $\mathrm{~N}$ \\
\hline Turdus nigriceps & o & 0.33 & o & DT \\
\hline Aimophila strigiceps & o & 0.07 & o & DS \\
\hline Atlapetes fulviceps & 0.23 & o & o & DS \\
\hline Catamenia analis & o & 0.13 & o & DT \\
\hline Catamenia inornata cordobensis* & $\mathrm{o}$ & o & 0.03 & DT \\
\hline Myioborus brunniceps & o & o & 0.17 & DT \\
\hline Phrygilus unicolor ${ }^{+}$ & 0.37 & o & o & DS \\
\hline Poospiza baeri ${ }^{+}$ & 0.07 & 0.17 & o & DS \\
\hline Poospiza erythrophrys & 0.07 & o & o & DS \\
\hline Saltator aurantiirostris & 0.03 & o & o & DS \\
\hline Thlypopsis sordida & 0.07 & o & o & DS \\
\hline Thraupis bonariensis & 0.20 & 0.20 & o & DS \\
\hline Zonotrichia capensis & 3.2 & 1.73 & 0.07 & $\mathrm{~N}$ \\
\hline Carduelis atrata ${ }^{+}$ & 0.20 & 0.10 & o & DS \\
\hline Carduelis magellanica & 0.07 & 0.83 & o & DT \\
\hline Carduelis uropygialis & 0.10 & o & o & DT \\
\hline Molothrus bonariensis & o & 0.13 & o & $\mathrm{N}$ \\
\hline
\end{tabular}


Table 2. Species richness, diversity and functional group composition estimated for bird communities of North, Centre and South sites of Polylepis australis forest of Argentina. ER: encounter rates expressed as the number of detections per 10-minute survey period. $\mathrm{S}_{\text {obs Mau Tau }}$ sample species richness from sample-based rarefaction curves. $\mathrm{S}_{\text {boot }}$ : bootstrap estimator; 1/D: Simpson's index. Different letter shows significant differences $(P<0.05)$.

\begin{tabular}{|c|c|c|c|}
\hline & \multicolumn{3}{|l|}{ Sites } \\
\hline & North ( \pm SE) & Centre $( \pm \mathrm{SE})$ & South $( \pm \mathrm{SE})$ \\
\hline Mean ER & $0.32(0.13)$ & $0.28(0.08)$ & $0.13(0.03)$ \\
\hline Number of individuals (N) & 259 & 218 & 67 \\
\hline Species richness $\left(\mathrm{S}_{\mathrm{obs} \text { Mau Tau }}\right)$ & $19.71(1.13) \mathrm{a}$ & $18.87(1.11) \mathrm{a}$ & $17.16(0.27) \mathrm{b}$ \\
\hline Species richness $\left(\mathrm{S}_{\text {boot }}\right)$ & $22.86(1.27) \mathrm{a}$ & $22.24(1.24) \mathrm{a}$ & $19.60(0.28) b$ \\
\hline Species diversity (I/D) & $6.02(0.03) \mathrm{a}$ & $8.88(0.31) b$ & $8.69(0.13) \mathrm{c}$ \\
\hline Equitability $\left(\mathrm{E}_{\mathrm{S}}\right)$ & $0.23(0.001) \mathrm{a}$ & $0.31(0.01) b$ & $0.51(0.01) \mathrm{c}$ \\
\hline Number of disturbance-sensitive Species (DS) & $15 \mathrm{a}$ & $11 b$ & $4 \mathrm{~b}$ \\
\hline Number of disturbance-tolerant Species (DT) & 8 & 9 & 7 \\
\hline Number of disturbance-neutral Species (N) & 3 & 6 & 6 \\
\hline
\end{tabular}

2008). Besides forest quality, the surrounding vegetation may also be an important driver of bird communities; we found that the birds that use Polylepis forests are mainly species of neighbouring vegetation types (i.e., subtropical montane forest; shrubland/grassland). Thus, in agreement with observations of Lloyd $(2008 \mathrm{a}, \mathrm{b})$ in Peruvian Polylepis forest, the matrix exerts a significant influence on avifauna composition.

In South America, the southern range distribution of avian species highly associated with Polylepis forests (e.g., Tawny Tit-spinetail Leptasthenura yanacensis, Thick-billed Siskin Carduelis crassirostris, Giant Conebill Oreomanes fraseri) only reached the Northern site, with no records at Centre or South sites. Therefore, we were unable to find bird specialists of $P$. australis forests, in contrast to Herzog et al. (2003) and Lloyd (2008a,b) who detected many highly associated bird species in tropical Polylepis forests of Bolivia and Peru.

We found four species, broadly distributed in other vegetation types, which were present in the three sites surveyed: Leptasthenura fuliginiceps, Sappho sparganura, Turdus chiguanco, and Zonotrichia capensis. The Polylepis forest assemblage has a mixed origin of species associated with subtropical montane forest and species associated with shrublands and grasslands.

Regarding the habitat sensitive species group, the North site harboured significantly more disturbance-sensitive species than tolerant or neutral species. The low similarity in composition of bird communities along the gradient, beta diversity, showed a species turnover from disturbance-sensitive species to species relatively resilient to human disturbance. Generalist and dispersive species such as House Wren Troglodytes aedon, Zonotrichia capensis, and Eared Dove Zenaida auriculata, became abundant towards the South to the detriment of forest species. Two possible factors that can compound the absence of habitat disturbance-sensitive species in the South site are the structural simplification of the vegetation and the high degradation of Polylepis forest. Most Polylepis specialists are insectivorous and therefore both vegetation structure and habitat disturbance (mainly fire) may reduce food resources for them (J. Cahill in litt.). Similar patterns of beta bird diversity changes were detected in a gradient of disturbed forest of central Argentina where increasing fire pressure caused an important structural simplification of the habitat (Albanesi et al. 2008), in forests of the tropical Andes (O'Dea and Whittaker 2007) and, in logged versus unlogged forest of Bolivia (Felton et al. 2008).

Of the total species recorded, two (Olrog's Grey-flanked Cincloides Cincloides oustaleti olrogi and Plain-coloured Seedeater Catamenia inornata cordobensis) are endemic subspecies that we recorded in the South site (EBA 058) and four (Black Siskin Carduelis atratus, Plumbeous Sierra-finch Phrygilus unicolor, Streak-fronted Thornbird Phacellodomus striaticeps, and 

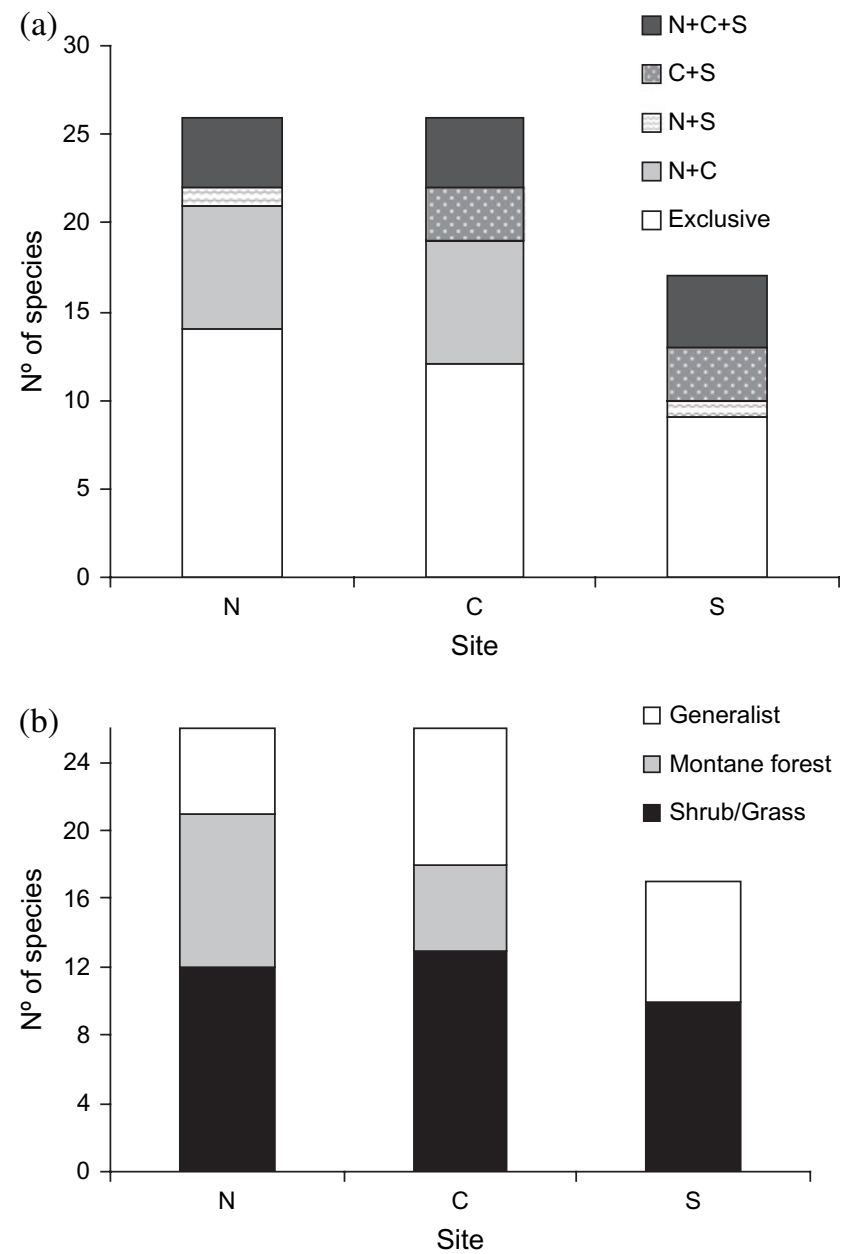

Figure 2. Bird species richness in North (N), Centre (C), and South (S) sites along the latitudinal range of Polylepis australis in Argentina. (a) Number of species recorded in the three sites $(\mathrm{N}+\mathrm{C}+\mathrm{S})$, shared by two sites, or exclusive to one site and (b) number of species associated to subtropical montane forest, shrubland or grasslands, or not associated to a particular habitat (generalist).

Tucuman Mountain Finch Poospiza baeri) are typical Polylepis forests birds (Fjeldså 2002) that we recorded in the North and Centre sites (EBA 057). We also recorded four species of conservation concern: Poospiza baeri, a globally threatened species categorized as 'Vulnerable' by Birdlife International (2007) due to its restricted range and the loss of its natural habitat as a consequence of land conversion and use of pesticides (Peris 1997, Di Giácomo 2005). Grey-hooded Parakeet Bolborhynchus aymara, Leptasthenura fuliginiceps, and Turdus chiguanco are declining at regional level in the South site (Miatello et al. 1999), as a consequence of habitat loss caused primarily by fires and overgrazing. Livestock overgrazing in the South site is responsible of transformation of woodlands into grasslands and eroded rock surfaces (Cingolani et al. 2008). This degradation process has negatively affected bird diversity at the landscape level (García et al. 2008). 


\section{Implications for conservation}

This work is a first approach to understanding the assemblage and status of the avifauna in Polylepis australis forest along its distribution range in Argentina and it constitutes a starting point for more comprehensive studies. Initial management recommendations can be formulated on the basis of our study. We recommend the expansion of Calilegua National Park to include the $P$. australis belt in its northern ranges - a project that is being considered by the present National Parks Administration. This is especially important as these Polylepis forest sites harbour many disturbance-sensitive species, which will disappear if these areas are degraded. We also recommend managing Quebrada del Condorito National Park in the southern ranges to augment the complexity of forest structure and thus provide suitable habitat for disturbancesensitive species.

\section{Acknowledgments}

We are very grateful to American Bird Conservancy for providing financial support for this research and the National Parks Administration for granting study permits. We also give thanks to J. Cahill and an anonymous referee who made important suggestions that greatly improved the MS. L.M.B. and D.R. are researchers from CONICET. L.R. and E. M. have doctoral fellowships from YPF Foundation and CONICET, respectively.

\section{References}

Albanesi, S. A., Dardanelli, S., Heredia, J. and Bellis, L. M. (2008) Caracterización de la avifauna en ambientes con distinta historia de fuego en las Sierras Chicas de Córdoba, Argentina. San Martín de los Andes, Argentina: XII RAO.

Barlow, J., Peres, C. A., Henrique, L. M. P., Stouffer, P. C. and Wunderle, J. M. (2006). The responses of understorey birds to forest fragmentation, logging and wildfires: An Amazonian synthesis. Biol. Conserv. 128: 182-192.

Bennett, A. F., Hinsley, S. A., Bellamy, P. E., Swetnam, R. D. and MacNally, R. (2004) Do regional gradients in land-use influence richness, composition and turnover of bird assemblages in small woods? Biol. Conserv. 119: 191-206.

Bibby, C. J., Burgess, N. D. and Hill, D. A. (1992) Bird census techniques. London, UK: Academic Press.

BirdLife International (2007) Species factsheet: Poospiza baeri. Downloaded from http://www.birdlife.orgon 22/2/2008.

Cabido, M. and Acosta, A. (1985) Estudio fitosociológico en bosques de Polylepis australis BITT. ("Tabaquillo") en las Sierras de Córdoba. Argentina. Documents Phytosociologiques. N.S. 9: 385-400.
Cabrera, A. (1976) Regiones fitogeográficas argentinas. Buenos Aires, Argentina: Ed. Acme.

Cahill, J. R. A. and Matthysen, E. (2007) Habitat use by two specialist birds in high-Andean Polylepis forests. Biol. Conserv. 40: 62-69.

Cingolani, A. M., Renison, D., Zak, M. R. and Cabido, M. R. (2004) Mapping vegetation in a heterogeneous mountain rangeland using Landsat data: an alternative method to define and classify land-cover units. Remote Sens. Environ. 92: 84-97.

Cingolani, A. M., Renison, D., Tecco, P., Gurvich, D. and Cabido, M. (2008) Predicting cover types in a mountain range with long evolutionary grazing history: a GIS approach. J. Biogeog. 35: 538-551.

Coblentz, D. and Keating, P. L. (2008) Topographic controls on the distribution of tree islands in the high Andes of south-western Ecuador. J. Biogeog. 35: 2026-2038.

Colwell, R. K. (2006) EstimateS: Statistical estimation of species richness and shared species from samples. Version 8.o, <http:// viceroy.eeb.uconn.edu/EstimateS $>$.

Colwell, R. K. and Coddington, J. A. (1994) Estimating terrestrial biodiversity through extrapolation. Phil. Trans. R. Soc. 345: 101118. 
Dardanelli, S., Nores, M. L. and Nores, M. (2006) Minimum area requirements of breeding birds in fragmented woodland of Central Argentina. Divers. Distrib. 12: 687-693.

Di Giácomo, A. S. (2005) áreas de conservación de aves en la Argentina. Sitios prioritarios para la conservación de la biodiversidad. Temas de Naturaleza y Conservación 5: I-514.

Enrico, L., Funes, G. and Cabido, M. (2004) Regeneration of Polylepis australis Bitt. in the mountains of central Argentina. For. Ecol. Manage. 190: 301-309.

Felton, A., Wood, J., Felton, A. M., Hennessey, B. and Lindenmayer, D. B. (2008) Bird community responses to reduced-impact logging in a certified forestry concession in lowland Bolivia. Biol. Conserv. 141: 545555 .

Fjeldså, J. (1993) The avifauna of the Polylepis woodlands of the Andean highlands: the efficiency of basing conservation priorities on the patterns of endemism. Bird Conserv. Internatn. 3: 37-55.

Fjeldså, J. (2002) Key areas for conserving the avifauna of Polylepis forests. Ecotropica 8: 125-131.

Fjeldså, J. and Kessler, M. (1996) Conserving the biological diversity of Polylepis woodlands of the highland of Peru and Bolivia. A contribution to sustainable natural resource management in the Andes. Copenhagen, Denmark: NORDECO.

Fjeldså, J. and Krabbe, N. (1990) Birds of the high Andes. Copenhagen, Denmark: Zoological. Museum, University of Copenhagen.

García, C., Renison, D., Cingolani, A. M. and Fernández-Juricic, E. (2008) Avifaunal changes as a consequence of large scale livestock exclusion in the mountains of Central Argentina. J. Appl. Ecol. 45: 351360 .

Heil, L., Fernández-Juricic, E., Renison, D., Cingolani, A. M. and Blumstein, D. T. (2007) Avian responses to tourism in the biogeographically isolated high Córdoba Mountains, Argentina. Biodivers. Conserv. 16: 1009-1026.

Herzog, S. K., Soria, R. A. and Matthysen, E. (2003) Seasonal variation in avian commu- nity composition in a high-Andean Polylepis (Rosaceae) forest fragment. Wilson Bull. 115: 438-447.

Hunzinger, H. (1995) La precipitación horizontal: su importancia para el bosque y a nivel de cuencas en la Sierra de San Javier, Tucumán, Argentina. Pp. 163-174in A. D. Brown and H. R. Grau, eds. Investigación, conservación y desarrollo en las selvas subtropicales de montañas. Tucumán, Argentina: Proyecto de Desarrollo Agroforestal/ L.I.E.Y Secretaria de Ambiente y Desarrollo Sustentable.

Jameson, J. and Ramsay, P. M. (2007) Changes in high-altitude Polylepis forest cover and quality in the Cordillera de Vilcanota, Peru, 1956-2005. Biol. Conserv. 138: 38-46.

Kessler, M. (2000) Observations on a humaninduced fire event at a humid timberline in the Bolivian Andes. Ecotropica 6: 89-93.

Kessler, M. (2002) The Polylepis problem: where do we stand? Ecotropica 8: 97-110.

Kessler, M., Herzog, S. K., Fjeldså, J. and Bach, K. (2001) Species richness and endemism of plant and bird communities along two gradients of elevation, humidity and land use in the Bolivian Andes. Divers. Distrib. 7: 61-77.

Lee, D. C. and Marsden, S. J. (2008) Adjusting count period strategies to improve the accuracy of forest bird abundance estimates from point transect distance sampling surveys. Ibis 150: 315-325.

Lloyd, H. (2008a) Influence of within-patch habitat quality on high-Andean Polylepis bird abundance. Ibis 150: 735-745.

Lloyd, H. (2008b) Abundance and patterns of rarity of Polylepis birds in the Cordillera Vilcanota, southern Perú: implications for habitat management strategies. Bird Conserv. Internatn. 18:164-180.

Lloyd, H. and Marsden, S. J. (2008) Bird community variation across Polylepis woodland fragments and matrix habitats: implications for biodiversity conservation within a high Andean landscape. Biodiv. Conserv. 17: 2645-266o.

Magurran, A. E. (1988) Ecological diversity and its measurement. Princeton, NJ: Princeton University Press. 
Mao, C. X., Colwell, R. K. and Chang, J. (2005) Estimating the species-accumulation curve using mixtures. Biometrics 61: 433-441.

Mazar Barnett, J. and Pearman, M. (200I) Lista comentada de las aves Argentinas. Barcelona, Spain: Lynx Ediciones.

Miatello, R., Baldo, J., Ordano, M., Rosacher, C. and Biancucci, L. (1999) Avifauna del Parque Nacional Quebrada del Condorito y Reserva Hídrica Provincial Achala, Córdoba, Argentina: una lista comentada. Córdoba, Argentina: Provincia de Córdoba. Secretaría de Agricultura, Ganadería y Recursos Renovables.

Narosky, T. and Yzurieta, D. (2003) Guía para la identificación de las aves de Argentina y Uruguay. Buenos Aires, Argentina: Vazquez Mazzini Editores.

O'Dea, N. and Whittaker, R. E. (2007) How resilient are Andean montane forest bird communities to habitat degradation? Biodiv. Conserv. 16: 1131-1159.

Ordano, M. (1996) Estudio de una comunidad de aves altoserrana (Córdoba, Argentina) durante un ciclo anual. Revista de la Asociación de Ciencias de la Nat Litoral 27: 83-94.

Peris, S. J. (1997) Notes on the breeding biology and population density of the Tucumán Mountain-finch (Poospiza baeri; Aves: Emberizidae) in Argentina, with description of nest and eggs. Revista Chilena de Historia Natural 70: 221-224.

Ralph, C. J., Sauer, J. R. and Droege, S. eds. (1995) Monitoring bird populations by point counts. Albany, CA: Pacific Southwest Research Station, Forest Service, US Department of Agriculture. Gen. Tech. Rep. PSW-GTR- 149.

Renison, D., Cingolani, A. M. and Schinner, D. (2002) Optimizing restoration of Polylepis australis woodlands: when, where and how to transplant seedlings to the mountains? Ecotropica 8: 219-224.

Renison, D., Hensen, I., Suarez, R. and Cingolani, A. M. (2006) Cover and growth habit of Polylepis woodlands and shrublands in the mountains of central Argentina: human or environmental influence? J. Biogeog. 33: 876-887.
Renison, D., Bellis, L. M., Guzmán, G. F., Grau, R., Pacheco, S., Rivera, L., Politi, N., Martin, E., Cuyckens, E., Marcora, P., Robledo, G., Cingolani, A. M., Perasso, L, Cornell, F., Dominguez, J., Landi, M. and Hensen, I. (in press). Estado de conservación de los bosques Argentinos de Polylepis y su avifauna. In H. Arnal, ed. Una contribución al conocimiento de los bosques altoandinos de Polylepis: distribución, diversidad y estado actual de los bosques más altos del mundo. Lima, Perú: American Bird Conservancy - Comunidad Andina.

Stattersfield, A. J., Crosby, M. J., Long, A. J. and Wegge, D. C. (1998) Endemic bird areas of the world: priorities for biodiversity conservation. Cambridge, UK: BirdLife International. Conservation Series No. 7.

Stirling, G. and Wilsey, B. (2001) Empirical relationships between species richness, evenness, and proportional diversity. Am. Nat. 158: 286-299.

Stotz, D. F., Fitzpatrick, J. W., Parker, T. A. and Moskovits, D. K. (1996) Neotropical birds. Ecology and conservation. Chicago, USA: University of Chicago Press.

Teich, I., Cingolani, A. M., Renison, D., Hensen, I. and Giorgis, M. A. (2005) Do domestic herbivores retard Polylepis australis Bitt. woodland recovery in the mountains of Cordoba, Argentina? For. Ecol. Manage. 219: 229-241.

Terborgh, J. (1977) Bird species diversity on an Andean elevational gradient. Ecology 58: 1007-1019.

Torres, R., Renison, D., Hensen, I., Suárez, R. and Enrico, L. (2008) Polylepis australis' regeneration niche in relation to seed dispersal, site characteristics and livestock density. For. Ecol. Manage. 254: 255-260.

Watson, J. E., Whitttaker, R. J. and Dawson, T. P. (2004) Habitat structure and proximity to forest edge affect the abundance and distribution of forest-dependent birds in tropical coastal forest of southeastern Madagascar. Biol. Conserv. 120: 311-327.

Zar, J. H. (1984) Biostatistical analysis. New Jersey, USA: Prentice-Hall. 
LAURA M. BELLIS*, DANIEL RENISON

CONICET, Cátedra de Ecología, Facultad de Ciencias Exactas Físicas y Naturales, Universidad Nacional de Córdoba, Velez Sarsfield 299, (500o) Cordoba, Argentina.

LUIS RIVERA, FRANCISCO CORNELL

Fundación CEBIO, Roca 44, S. S. de Jujuy, (460o) Jujuy, Argentina.

\section{NATALIA POLITI}

Department of Wildlife Ecology, University of Maine, U.S.A.

Current address: Fundación CEBIO, Roca 44, S. S. de Jujuy, (460o) Jujuy, Argentina.

\section{EDUARDO MARTÍN}

Centro de Zoología Aplicada, Universidad Nacional de Córdoba, Argentina.

Current address: Laboratorio de Investigaciones Ecológicas de las Yungas (LIEY), Universidad Nacional de Tucumán, Ciudad Universitaria de Horco Molle, Yerba Buena, Tucumán,

Argentina.

M. LAURA PERASSO

Cátedra de Ecología, Facultad de Ciencias Exactas Físicas y Naturales, Universidad Nacional de Córdoba, Velez Sarsfield 299, (500o) Cordoba, Argentina.

*Author for correspondence; e-mail: lbellis@com.uncor.edu

Received 21 June 2008; revision accepted 5 November 2008 